\section{Uptake of Formalin by Brain Tissue from Dogs killed at various Stages of Development}

EARLIER work ${ }^{1}$ with fresh canine brains has shown that there is a linear increase in the dry matter content from birth to 6 weeks of age (10 per cent to 19 per cent) and then a more gradual maturation to the adult level of 20 per cent. A rapid increase in brain volume up to 6 weeks of age was also found.

Histological examination of the occipital and frontal cortex revealed changes in cell density with age ${ }^{2-4}$, there being a great reduction in cell density from birth to 6 weeks of age (250-60 cells per unit area) followed by a gradual reduction to the adult density of 40-45 cells per unit area.

Fourteen inbred Beagle dogs ranging from birth to adulthood were used in the present investigation; under deep barbiturate anaesthesia seven dogs were perfused with heparinized normal saline followed by formalin; the dura mater was removed from the brain, which was then immersed in formalin for 4 weeks. After this time the brain was dissected and the parts were weighed before and after maceration and desiccation for 5 days in a drying oven. The parts consisted of medulla and pons (up to the superior colliculi) and cerebral cortex (excluding olfactory lobes). After desiccation the remaining weight of each part was determined and expressed as a percentage of the original formalin-fixed weight before desiccation (Fig. 1). Seven controls of corresponding ages were similarly treated, with the omission of formalin perfusion and fixation.

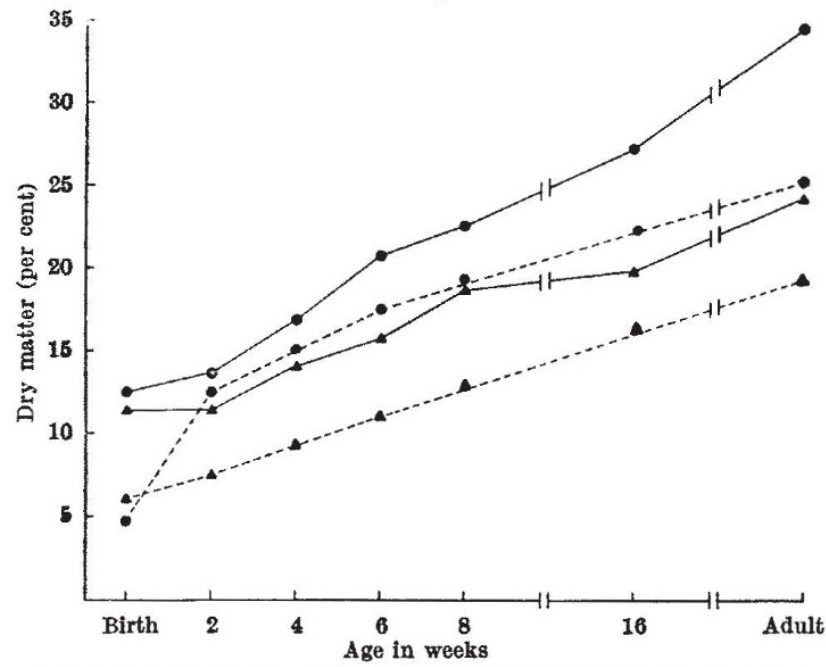

Fig. 1. Percentage of dry matter in different parts of the brain of the dog at different ages and after formalin fixation. Medulla; $\boldsymbol{\Delta}$, cerebrum. Broken lines, formalin fixed

It was found that the percentage of dry matter was least at birth and increased gradually with age. Some evidence of caudocephalad encephalization was found in various parts of the brain, the most caudal region having the greatest dry matter content.

It would appear that the amount of formalin taken up by central nervous tissue is a function of cell size and changes in cell density with age. In young specimens where the cell density is greatest there is consequently a reduction in the intercellular space, and because the average size of the neurone does not reach adult dimensions until 4 weeks of age (neuroblastiform at birth in the cerebrum), the interperikaryal space is consequently less in younger specimens ${ }^{4}$. The reduction in dry matter content following fixation is at present under investiga. tion; it has been suggested that phospholipids are leached during fixation.

Calculation of the dry matter content after desiccation of fresh and formalin-fixed specimens therefore gives an indirect estimate of the intra- and extra-cellular content of the brain which can be correlated with other aspects of post-natal development. Higher dry matter percentages are found in the more caudal parts of the brain in accordance with greater aggregation and packing of neurones and nerve tracts as compared with the cytoarchitectonics of the cerebral cortex ${ }^{5,6}$.

These findings were correlated with previous data on the developing canine brain. The percentage dry matter of formalin-fixed tissue was directly correlated $(P<0.01)$ with cell density and a 10 per cent loss in the percentage dry matter content of fresh brain predictable after fixation.

This work was supported in part by U.S. Public Health Service training grant $C R T 5013$ from the National Institutes of Health.

The Jackson Laboratory, M. W. Fox

Bar Harbor, Maine.

1 Fox, M. W., Amer. J. Vet. Res., 24, 1240 (1963).

2 Cummings, J. N., Child Neural. and Cerebral Palsy, 4, 42 (1960).

${ }^{3}$ Fox, M. W., J. Amer. Vet. Med. As8., 48, 968 (1963).

"Fox, M. W., Growth (in the press).

${ }^{5}$ Singer, M., The Brain of the Dog in Section (Philadelphia, W. B. Saunders Co., 1962).

- Adrianov, C. C., and Mering, T. A., Atlas of the Brain of the Dog (Moscow, Moscow State Publishing House for Medical Literature (in Russian), 1959).

\section{Calcium Exchangeability in Frog Sartorius Muscle during Potassium Depolarization}

The release of calcium from the membrane or from endoplasmic reticulum is regarded as the main process in the mechanism provoking muscle contraction. The system of membrane control of contractile activity in the fast muscle fibres has several properties for which similar terminology was proposed as for the membrane control of $\mathrm{Na}$ conductance ${ }^{1}$. In this work some properties of the Ca-releasing system were examined by using ${ }^{45} \mathrm{Ca}$ and the results are discussed in terms of membrane control of $\mathrm{Na}$ conductance.

Sartorii of the frog Rana temporaria were used. The experiments were carried out in Ringer's solution containing: $\mathrm{NaCl}, 115 \mathrm{mM}$; $\mathrm{KCl}, 2.5 \mathrm{mM} ; \mathrm{CaCl}_{2}, 1.8 \mathrm{mM}$; $\mathrm{Na}_{2} \mathrm{HPO}_{4}, 2.15 \mathrm{mM}$; $\mathrm{NaH}_{2} \mathrm{PO}_{4}, 0.85 \mathrm{mM}$. High-CaCl Ringer's was made without phosphates. When increasing the $\mathrm{K}$ concentration the corresponding amount of $\mathrm{KCl}$ was substituted for $\mathrm{NaCl}$. One of the pair of sartorii of each animal was used as an experimental muscle; the other as a control. Two series of experiments were carried out. In the first series the control muscle was exposed for $15 \mathrm{~min}$ to ${ }^{45} \mathrm{Ca}$ Ringer's solution (RS). The experimental muscle was exposed for $5 \mathrm{~min}$ to ${ }^{45} \mathrm{Ca} \mathrm{RS}$ and for $10 \mathrm{~min}$ to ${ }^{45} \mathrm{Ca} \mathrm{RS}$ with high $\mathrm{K}$. The muscles were washed four times for $5,10,25$ and $50 \mathrm{~min}$ in non-radioactive RS to remove ${ }^{45} \mathrm{Ca}$ from the extracellular space and from the superficial binding sites of the fibres ${ }^{2}$. They were then ashed and the radioactivity was counted. In the second series the control muscle was immersed for 40 (or 10) min in non-radioactive $\mathrm{RS}$, then the ${ }^{45} \mathrm{Ca} \mathrm{RS}$ was applied for $15 \mathrm{~min}$. The experimental muscle was exposed for 40 (or 10) $\mathrm{min}$ to non-radioactive high-K RS, then the high-K ${ }^{45} \mathrm{Ca}$ RS was applied for $15 \mathrm{~min}$. To prevent twitching, $10^{-4} \mathrm{M}$ cocaine was added in all solutions.

In preliminary kinetic experiments it was found that the estimation of $\mathrm{Ca}$ influx in the sartorii of Rana tem. poraria on the basis of the slow component does not represent the real exchange of cellular Ca. For this reason the changes in Ca movements were evaluated only as the changes in $\mathrm{Ca}$ exchangeability. The values in Fig. 1 concerning the values between 20 and $50 \mathrm{mM} \mathrm{K}$ do not, therefore, represent quantitative relation between $\mathrm{Ca}$ exchange and $\mathbf{K}$ concentration.

The changes in $\mathrm{Ca}$ exchangeability at different values of depolarization are shown in Fig. 1. A big increase in $\mathrm{Ca}$ exchangeability was found both at the beginning of depolarization and after $40 \mathrm{~min}$ depolarizing with $15-20$ $\mathrm{mM} \mathrm{K}$. At greater depolarization a big increase in ex- 